\title{
ANALISIS FAKTOR-FAKTOR YANG MEMENGARUHI DIVIDEND PAYOUT RATIO PADA PERUSAHAAN SEKTOR INDUSTRI YANG TERDAFTAR DI BURSA EFEK INDONESIA
}

\author{
Sunaryo \\ Accounting and Finance Department, Faculty of Economic and Communication, BINUS University \\ Jln. K. H. Syahdan No. 9, Palmerah, Jakarta Barat 11480 \\ sunaryo@binus.ac.id
}

\begin{abstract}
The primary objective of this research is to learn the effect among return on assets (ROA), current ratio (CR), debt to equity ratio (DER), debt to total assets (DTA), and net income after tax (NIAT) with dividend payout ratio (DPR), either partially or simultaneously. Research used qualitative method with secondary data collected by purposive sampling from industrial companies sector listed in IDX and preceding journals of scientific articles. Research used simple regression to test the hypothesis simultaneously with $F$ test and t test for testing the partial hypothesis. Results of this research describe that return on assets (ROA) and net income aftar tax (NIAT) have significant effects to dividend payout ratio, but current ratio (CR), debt to equity ratio (DER), and debt to total assets do not have significant effects to dividend payout ratio. It is recommended to further research that the topic of this reseach can be continued using merchandising and distribution company groups, or service company groups either general or special, like: hotels, insurances, hospitals, and banks.
\end{abstract}

Keywords: factors effecting to dividend payout ratio, industrial companies sector, IDX

\begin{abstract}
ABSTRAK
Tujuan utama penelitian ini adalah untuk memahami pengaruh return on assets (ROA), current ratio (CR), debt to equty ratio (DER), debt to total assets (DTA), dan net income after tax (NIAT) terhadap dividend payout ratio (DPR), baik secara parsial maupun simultan. Penelitian menggunakan metode kualitatif menggunakan data sekunder yang dikumpulkan secara purposive sampling dari perusahaan sektor industri yang terdaftar di Bursa Efek Indonesia serta artikel jurnal ilmiah dari para peneliti sebelumnya. Penelitian menggunakan regresi sederhana dan uji $F$ untuk menguji hipotesis simultan dan menggunakan uji $t$ untuk menguji hipotesis parsial. Hasil penelitian menjelaskan bahwa return on assets (ROA) dan net income after tax (NIAT) secara signifikan berpengaruh terhadap dividend payout ratio (DPR), tetapi current ratio (CR), debt to equty ratio (DER), dan debt to total assets (DTA) secara signifikan tidak berpengaruh terhadap dividend payout ratio (DPR). Bagi para peneliti berikutnya disarankan agar penelitian dapat dilanjutkan dengan menggunakan kelompok perusahaan dagang dan distributor, atau kelompok perusahaan jasa, baik jasa umum maupun khusus, seperti hotel, asuransi, rumah sakit, dan bank.
\end{abstract}

Kata kunci: faktor yang memengaruhi dividend payout ratio, sektor perusahaan industri, BEI 


\section{PENDAHULUAN}

Manajemen perusahaan memiliki dua pilihan atas laba bersih setelah pajak yang dihasilkan dalam satu periode akuntansi (tahunan) yaitu yang akan diinvestasikan kembali ke perusahaan sebagai laba yang ditahan atau dibagikan kepada para pemegang saham dalam bentuk dividen. Dividen merupakan distribusi laba bersih setelah pajak kepada pemegang saham berdasarkan banyaknya jumlah lembar saham yang dimiliki. Dividend payout ratio merupakan rasio keuangan yang digunakan untuk menentukan seberapa besar laba bersih setelah pajak yang akan dibagikan kepada para pemegang saham, khususnya dividen kas. Para investor umumnya menghendaki pembagian dividen tunai karena akan membantu mengurangi ketidakpastian dalam investasi. Sedangkan manajemen perusahaan dividen kas merupakan arus kas keluar yang umumnya ditahan oleh majamen untuk persiapan melunasi hutang baik utang jangka pendek maupun jangka panjang.

Brigham dan Houston (2009) menyatakan bahwa nilai perusahaan tidak ditentukan oleh besar kecilnya dividend payout ratio, tetapi ditentukan oleh kemampuan dasar perusahaan untuk menghasilkan laba, dan investor merasa lebih aman memperoleh pendapatan berupa dividen daripada capital gain serta menginginkan menerima dividen yang relatif stabil. Wirjolukito dkk (2003) menyatakan: "The harder we look at the dividend pictures, the more it seems like a puzzle, with pieces that just do not fit together." Oleh karena itu, penelitian mengenai faktor-faktor yang memengaruhi kebijakan pembagian dividen perlu lebih banyak dilakukan; dan selama ini hasilnya berbeda-beda dari beberapa peneliti sebelumnya. Sartono (2001) menyatakan bahwa dividend payout ratio ditentukan oleh (1) kebutuhan dana perusahaan, (2) likuiditas perusahaan, (3) kemampuan meminjam perusahaan, (4) kondisi pemegang saham, dan (5) stabilitas dividen. Di Indonesia penelitian berkaitan dengan dividend payout ratio banyak dilakukan namun hasilnya berbeda-beda.

Berdasarkan hasil penelitian Marlina dan Danica (2009), Nuringsih (2005), dan Suharli (2007), dinyatakan bahwa return on asset secara signifikan berpengaruh terhadap dividend payout ratio. Sedangkan menurut Handayani dan Hadinugroho (2009), Sudarsi (2002), dan Sutrisno (2001), return on asset secara signifikan tidak berpengaruh terhadap dividend payout ratio. Hasil penelitian Sulastri dan Harmadi (2009) menyatakan bahwa current ratio secara signifikan berpengaruh terhadap dividend payout ratio. Sementara, Sunarto dan Kartika (2003) menyatakan bahwa current ratio secara signifikan tidak berpengaruh terhadap dividend payout ratio. Sutrisno (2001) dan Prihantoro (2003), hasil penelitian mereka menyatakan bahwa debt to equity ratio secara signifikan berpengaruh terhadap dividend payout ratio. Namun Marlina dan Danica (2009), Maria dkk (2007) menyatakan debt to equity ratio secara signifikan tidak berpengaruh terhadap dividend payout ratio. Sulastri dan Harmadi (2009), Sunarto dan Kartika (2003) menyatakan bahwa laba bersih setelah pajak secara signifikan berpengaruh terhadap dividend payout ratio. Sedangkan Manurung dan Siregar (2009), laba bersih setelah pajak secara signifikan tidak berpengaruh terhadap dividend payout ratio. Berdasarkan perbedaan teori dan hasil penelitian tersebut, faktor-faktor yang berpengaruh tehadap dividend payout ratio menarik untuk diteliti. Dalam pelaksanaannya, penelitian menggunakan perusahaan sektor industri yang terdaftar di Bursa Efek Indonesia.

Rumusan masalah dalam penelitian ini adalah sebagai berikut. Pertama, apakah return on asset secara signifikan berpengaruh terhadap dividend payout ratio. Kedua, apakah current ratio secara signifikan berpengaruh terhadap dividend payout ratio. Ketiga, apakah debt to equity ratio secara signifikan berpengaruh terhadap dividend payout ratio. Keempat, apakah debt to equity ratio secara signifikan berpengaruh terhadap dividend payout ratio. Kelima, apakah net income after tax secara signifikan berpengaruh terhadap dividend payout ratio. Keenam, apakah return on asset, current ratio, debt to equity ratio, debt to total assets, dan net income after tax secara bersama-sama signifikan terhadap dividend payout ratio. 
Tujuan utama dalam penelitian ini adalah untuk mengetahui dan memahami apakah secara persial atau individual seperti return on asset, current ratio, debt to equity ratio, debt to total assets, dan net income after tax berpengaruh secara signifikan terhadap dividend payout ratio. Selain itu, penelitian bertujuan untuk mengetahui dan memahami apakah return on asset, current ratio, debt to equity ratio, debt to total assets, dan net income after tax secara bersama-sama berpengaruh secara signifikan terhadap dividend payout ratio. Hasil penelitian diharapkan bermanfaat sebagai dasar pertimbangan bagi para investor dalam pengambilan keputusan investasi saham pada perusahaan yang terdaftar di Bursa Efek Indonesia, khususnya kelompok perusahaan sektor industri untuk tujuan memperoleh dividen secara rutin dan stabil. Penelitian dibagi dalam enam tahap: tahap pertama pendahuluan, tahap kedua tinjauan pustaka, tahap ketiga metode penelitian, tahap keempat pembahasan, tahap kelima simpulan, dan tahap keenam daftar pustaka.

\section{Tinjauan Pustaka}

Menurut Ikatan Akuntan Indonesia (2009), dalam PSAK No. 23, dijelaskan bahwa dividen sebagai distribusi laba kepada pemegang saham sesuai dengan proporsi mereka dari jenis modal tertentu. Hanafi (2004) menyatakan bahwa dividen merupakan kompensasi yang diterima oleh pemegang saham, di samping capital gain. Dividen ini untuk dibagikan kepada para pemegang saham sebagai keuntungan dari laba perusahaan; dan dividen ditentukan berdasarkan rapat umum anggota pemegang saham serta jenis pembayarannya, tergantung pada kebijakan pimpinan. Sedangkan menurut Gallegher dan Andrew (1997): "Dividends are the cash payment that corporation make to their common stockholder." Berdasarkan definisi, secara umum dapat disimpulkan bahwa dividen sebagai kompensasi yang dibayar perusahaan kepada pemegang saham sebagai laba yang diperoleh berdasarkan jumlah yang diinvestasikan.

Menurut Stice dan Skousen (2007), dividend divided by cash dividend (dalam bentuk tunai), stock dividend (dalam bentuk saham tambahan), property dividend (dalam bentuk harta), dan interim dividend (dibagikan sebelum tahun buku perseroan berakhir). Dividend payout ratio (rasio pembayaran dividen) merupakan faktor yang harus dipertimbangkan, sedangkan jumlah dividen yang dibayarkan tergantung dari kebijakan perusahaan. Jika seluruh laba yang dihasilkan dibayarkan sebagai dividen, perusahaan tidak memiliki cadangan dana untuk melakukan reinvesment; dan sebaliknya jika seluruh laba yang dihasilkan dipertahankan, kepentingan pemegang saham diabaikan, sehingga perusahaan kehilangan kesempatan mendapatkan investor baru. Adapun tujuan utama pembagian dividen adalah untuk memaksimumkan kemakmuran para pemegang saham karena dividen yang dibayarkan akan memengaruhi harga pasar saham. Oleh karena itu, kinerja perusahaan diharapkan baik di mata para investor dan menunjukkan perusahaan mampu menghadapi gejolak ekonomi. Sebagian investor memandang bahwa risiko dividen lebih rendah dibandingkan dengan risiko capital gain, serta dividen dapat digunakan sebagai alat komunikasi antara manajemen dengan pemegang saham. Aspek utama dalam kebijakan dividen adalah alokasi penentuan besarnya bagian laba sebagai laba yang ditahan dan bagian laba sebagai pembayaran dividen kepada pemegang saham. Kebijakan dividen merupakan jenis keputusan keuangan yang memengaruhi jumlah pendapatan yang akan dibagikan kepada pemegang saham atau akan menahannya sebagai laba yang ditahan digunakan untuk melakukan investasi kembali.

Sartono (2001) menyatakan bahwa faktor-faktor yang memengaruhi kebijakan dividen adalah (1) kebutuhan dana perusahaan, (2) likuiditas, (3) kemampuan meminjam, (4) keadaan pemegang saham, dan (5) stabilitas dividen. Sedangkan menurut Hanafi (2004), faktor-faktor yang memengaruhi rasio pembayaran dividen adalah (1) kesempatan investasi, (2) likuiditas dan profitabilitas, (3) akses ke pasar keuangan, (4) stabilitas pendapatan, dan (5) pembatasan-pembatasan yang dilakukan pihak di luar perusahaan karena perjajian utang. 
Brigham dan Ehrdhardt (2008:133), mengatakan return on assets (ROA) adalah "ratio of net income to total assets." Lebih lanjut, "ROA is net income available to common stockholders divided by total assets." Sudarsi (2002) menyatakan ROA merupakan proksi dari profitabiliatas dan faktor profitabilitas berpengaruh terhadap kebijakan dividen karena dividen merupakan sebagian dari laba bersih yang diperoleh perusahaan, dividen dibagikan jika perusahaan memperoleh laba. Laba yang layak dibagikan sebagai dividen setelah dikurangan beban bunga dan pajak. Makin besar laba perusahaan, makin besar pula bagian yang dibagikan sebagai dividen. Dari uraian, dapat disimpulkan bahwa return on assets secara signifikan berpengaruh terhadap dividend payout ratio.

Sartono (2001) menyatakan bahwa current ratio (rasio likuiditas) menunjukkan kemampuan perusahaan untuk membayar kewajiban keuangan jangka pendek dengan tepat waktu. Berdasarkan Bergevin (2002), fungsi dari rasio likuiditas adalah (1) mengetahui keadaan industri tertentu dan perkembangan perusahaan, (2) kemampuan perusahaan menjual barang dagangan dan menagih piutang usaha, (3) waktu penerimaan kas dari konversi current assets, (4) tanggal pembayaran current liability, dan (5) jumlah non-cash current assets seperti prepaid expenses. Current ratio merupakan current assets dibagi dengan current liabilities. Sedangkan Marlina dan Danica (2009), hanya perusahaan dengan likuiditas baik yang akan membagikan laba kepada pemegang saham berupa dividen dalam bentuk tunai. Penelitian menjelaskan bahwa current ratio menunjukkan makin besar kemampuan perusahaan dalam memenuhi kewajiban jangka pendeknya dan tingginya current ratio menunjukkan keyakinan investor terhadap kemampuan perusahaan membayar dividen. Berdasarkan uraian, dapat disimpulkan bahwa ada pengaruh yang signifikan antara currrent ratio dengan dividend payout ratio.

Income merupakan konteks laporan keuangan mendasar dan penting yang berguna sebagai dasar perhitungan perpajakan yang dikenal dengan nama taxable income, penentuan kebijakan pembayaran dividen, petunjuk investasi, dan pembuat keputusan. Income yang diakui merupakan jumlah maksimum yang dapat didistribusikan sebagai dividen dan ditahan untuk ekspansi perusahaan. Di dalam laba akuntansi terdapat berbagai komponen berupa kombinasi seperti: laba kotor, laba usaha, laba sebelum pajak, dan laba setelah pajak (net income after tax). Ikatan Akuntan Indonesia, sesuai PSAK No. 1 (2009), menjelaskan laporan laba rugi perusahaan disajikan sedemikian rupa yang menonjolkan berbagai unsur kinerja keuangan yang diperlukan bagi penyajian secara wajar. Laporan laba rugi minimal mencakup pos-pos seperti (1) pendapatan, (2) laba rugi usaha, (3) beban pinjaman, (4) bagian dari laba atau rugi perusahaan afiliasi dan asosiasi yang diperlukan dengan menggunakan metode ekuitas, (5) beban pajak, (6) laba atau rugi dari aktivitas normal perusahaan, (7) pos luar biasa, (8) hak minoritas, dan (9) laba atau rugi periode berjalan. Karakteristik net income after tax terdiri dari: (1) actual transactions, yaitu terjadinya pendapatan dan beban pada saat terjadinya transaksi, (2) postulat periodik yang mengacu pada kinerja keuangan pada periode bersangkutan, (3) prinsip revenue yang berkaitan dengan pengakuan pendapatan, (4) prinsip expenses yang berkaitan dengan pengukuran beban, dan (5) laba akuntansi harus patuh pada prinsip konservativisme yaitu pendapatan diakui jika direalisasikan sedangkan beban diakui walaupun belum direalisasikan. Net income after tax adalah salah satu faktor yang perlu diperhatikan sebelum menentukan kebijakan pembagian dividen karena dividen kas diambil dari sebagian laba bersih yang diperoleh perusahaan. Laba perusahaan yang layak dibagikan kepada para pemegang saham berupa dividen setelah perusahaan memenuhi kewajibannya seperti membayar beban bunga dan pajak. Dengan demikan net income after tax dapat memengaruhi dividend payout ratio. Mumaiza dan Nasution (2009) dalam hasil penelitiannya menunjukkan bahwa laba akuntansi dan laba tunai secara signifikan memengaruhi dividen. 


\section{METODE}

Penelitian menggunakan data sekunder berupa laporan keuangan perusahaan sektor industri yang terdaftar di Bursa Efek Indonesia (BEI) untuk tahun 2011 serta hasil penelitian yang dimuat di jurnal ilmiah dari para peneliti sebelumnya. Populasi penelitian adalah perusahaan sektor industri yang terdaftar di Bursa Efek Indonesia untuk tahun 2011 dan dipilih secara purposive sampling dengan alasan untuk mendapatkan sampel yang representatif sesuai dengan kriteria seperti: perusahaan sektor industri; perusahaan yang mempublikasikan laporan keuangannya tahun 2011; perusahaan yang menghasilkan laba untuk tahun 2011; laporan keuangannya sudah diaudit oleh kantor akuntan publik; perusahaan membagikan dividen tahun 2011; melaporkan laporan keuangannya dalam mata uang rupiah; dan memiliki pengelompokan current assets dan current liabilities dalam laporan keuangannya karena salah satu variabel independennya adalah current ratio. Berdasarkan kriteria tersebut diperoleh jumlah sampel sebanyak 50 perusahaan sektor industri. Variabel-variabel yang digunakan adalah untuk variabel bebas (independent variables), seperti: Return On Assets (ROA), Current Ratio (CR), Debt to Equity Ratio (DER), Debt to Total Assets (DTA), dan Net Income After Tax (NIAT). Sedangkan variabel terikat (dependent variable) adalah Dividend Payout Ratio. Variabel bebas dan terikat ini dipilih karena sesuai dengan dasar teoretis serta hasil penelitian dari para peneliti sebelumnya yang menghasilkan penelitian berbeda, sehingga variabel-variabel tersebut menarik untuk diteliti. Uji data yang digunakan adalah Kolmogorov-Smirnov Z untuk menguji normalitas data (harus lebih besar dari 0,05), serta model summary untuk mengetahui besarnya persentase sampel variabel independen yang diteliti atas jumlah populasi variabel independen (Adjusted R Square). Uji hipotesis yang digunakan adalah uji $\mathrm{F}$ (Anova) dengan menggunakan regresi sederhana $(\mathrm{Y}=\mathrm{a}+\mathrm{b} 1 \mathrm{X} 1+\mathrm{b} 2 \mathrm{X} 2$ +b3X3 +b4X4 +b5X5 +e), dengan signifikansi lebih kecil dari 0,05. Selain itu, uji t (parsial) dilakukan dengan signifikansi sebesar lebih kecil dari 0,05 dengan model hipotesis penelitian sebagai berikut:

Ha1: Secara bersama-sama terdapat pengaruh yang signifikan antara return on assets, current ratio, debt to equity ratio, debt to total assets, dan net income after tax terhadap dividend payout ratio.

Ha2: Terdapat pengaruh signifikan antara return on assets terhadap dividend payout ratio.

Ha3: Terdapat pengaruh signifikan antara current assets terhadap dividend payout ratio.

Ha4: Terdapat pengaruh signifikan antara debt to equity ratio terhadap dividend payout ratio.

Ha5: Terdapat pengaruh signifikan antara debt to total assets terhadap dividend payout ratio.

Ha6: Terdapat pengaruh signifikan antara net income after tax terhadap dividend payout ratio.

Jika hasil signifikannya lebih kecil dari 0,05 berarti signifikan; dan jika lebih besar dari 0,05, berarti tidak signifikan.

\section{HASIL DAN PEMBAHASAN}

Sampel dipilih secara purposive sampling sebanyak 50 dari 137 perusahaan sektor industri yang terdaftar di Bursa Efek Indonesia dengan proses seleksi sebagai berikut. Jumlah perusahaan sektor industri yang terdaftar di Bursa Efek Indonesia sebanyak 137, dikurangi dengan perusahaan sektor industri yang tidak menghasilkan laba tahun 2011 sebanyak 17, dikurangi dengan perusahaan sektor industri yang melaporkan laporan keuangannya tidak menggunakan mata uang rupiah 15, 
dikurangi perusahaan sektor industri yang tidak memiliki pengelompokan current assets dan current liabilities sebanyak 37 dikurangi perusahaan sektor industri yang tidak membagikan dividen tahun 2011 sebanyak 18.

Data pada Tabel 1 menunjukkan bahwa semua variabel bebas (independent variables) seperti return on assets (ROA), current ratio (CR), debt to equity ratio (DER), debt to total assets (DTO), dan net income after tax (NIAT), serta dividend payout ratio terdistribusi secara normal, karena Asymp. Siq (2-tailed) lebih besar dari 0,05 yaitu sebesar 0,138.

Tabel 1 Contoh Tes Kolmogorov-Smirnov

\begin{tabular}{|c|c|}
\hline & Unstandardised Residual \\
\hline $\mathrm{N}$ & 50 \\
\hline Normal Parameters: Mean & .0001767 \\
\hline Std. Deviation & .00745353 \\
\hline Most Extreme: Absoluute & .164 \\
\hline Differences: Positive & .164 \\
\hline Negative & -.117 \\
\hline Kolmogorov-Smirnov Z & 1.157 \\
\hline Asymp. Sig. (2-tailed) & .138 \\
\hline
\end{tabular}

Data pada Tabel 2 menunjukkan bahwa Adjusted R Square sebesar 0,995 berarti variabel bebas (independent variables) seperti return on assets (ROA), current ratio (CR), debt to equity ratio (DER), debt to total assets (DTA), dan net income aftar tax (NIAT) berpengaruh terhadap dividend payout ratio (DPR) sebesar 99,5\%. Sedangkan sisanya sebesar 0,05\% dipengaruhi oleh variabel bebas (independent variables) lainnya di luar penelitian ini. Sementara R Square sebesar 0,996, berarti variabel bebas (independent variables) seperti return on assets (ROA), current ratio (CR), debt to equity ratio (DER), debt to total assets (DTA), dan net income after tax (NIAT) mempunyai korelasi positif terhahap dividend payout ratio (DPR) sebesar 0,996.

Tabel 2 Model Summary ${ }^{\mathrm{b}}$

\begin{tabular}{lcrrr} 
Modell & R & R Square & Adjusted R Square & Std. Error of the Estimate \\
\hline 1 & $.998^{\text {a }}$ & .996 & .995 & .007796295806061 \\
\hline a. & Predictors: (Constant), ROA, CR, DER,DTA,NITA & \\
b. & Dependent Variables: DPR & &
\end{tabular}

Data pada Tabel 3 menunjukkan bahwa uji F (Anova) mempunyai nilai signifikan sebesar 0,000 lebih kecil dari 0,05. Hal itu berarti Ha1 diterima dan Ho1 ditolak atau signifikan, berarti model regresi untuk variabel bebas (independent variables) seperti return on assets (ROA), current ratio (CR), debt to equity ratio (DER), debt to total assets (DTA), dan net income after tax (NIAT) berpengaruh secara signifikan terhadap dividend payout ratio (DPR) dengan tingkat keyakinan sebesar 95\%. Dengan kata lain model regresinya adalah fit (layak).

Tabel 3 Anova ${ }^{b}$ (uji F)

\begin{tabular}{|c|c|c|c|c|c|c|}
\hline \multicolumn{2}{|c|}{ Model } & Sum of Squares & df & Mean Square & t & Sig. \\
\hline \multirow[t]{3}{*}{1} & Regression & .622 & 5 & .124 & 2.04753 & $.000^{\mathrm{a}}$ \\
\hline & Residual & .003 & 44 & .000 & & \\
\hline & Total & .625 & 49 & & & \\
\hline
\end{tabular}

a. Predictors : (Constant), ROA,CR,DER,DTA,NIAT

b. Dependent Variable: DPR 
Data Tabel 4 dapat dibuat persamaan regresi sebagai berikut: $\mathrm{Y}=0,309-0,069 \mathrm{ROA}-$ 0,002CR + 0,003DER -0,005DTA + 0,824NIAT. Tabel 4 (uji t) menunjukkan bahwa variabel bebas (independent variables) seperti retun on assets (ROA) dan net income after tax (NIAT) secara signifikan berpengaruh terhadap variabel terikat (dependent variable) yaitu dividend payout ratio (DPR) karena memiliki nilai signifikansi lebih kecil dari 0,05 yaitu masing-masing sebesar 0,000, dan 0,000. Dengan kata lain Ha1 dan Ha5 diterima atau Ho1 dan Ho5 ditolak. Sedangkan variabel bebas (independent variables) seperti current ratio (CR), debt to equity ratio (DER), dan debt to total assets (DTA) secara signifikan tidak berpengaruh terhadap variabel terikat (dependent variable) yaitu divident payout ratio (DPR) karena nilai signifikansi lebih besar dari 0,05 yaitu masing-masing sebesar 0,544, 0,363, dan 0,367. Dengan kata lain Ha2, Ha3, dan Ha4 diterima atau Ho2, H03, dan Ho4 ditolak.

Para investor dalam memilih investasi saham pada perusahaan yang terdaftar di Bursa Efek Indonesia, khususnya pada kelompok sektor industri manufaktur secara khusus hendaknya memerhatikan besarnya rasio keuangan seperti return on assets dan net income after tax dengan memilih return on assets dan net income after tax yang besar namun tetap mempertimbangkan rasio keuangan lainnya sebagai pertimbangan penunjang seperti current ratio, debt to equity ratio, dan debt to total assets.

Tabel 4 Coefficient Regression ${ }^{\mathrm{a}}$ (uji t)

\begin{tabular}{|c|c|c|c|c|c|c|}
\hline \multirow{2}{*}{\multicolumn{2}{|c|}{ Model }} & \multicolumn{2}{|c|}{$\begin{array}{c}\text { Unstandardized } \\
\text { Coefficients }\end{array}$} & \multirow{2}{*}{$\begin{array}{c}\begin{array}{c}\text { Standardized } \\
\text { Coefficients }\end{array} \\
\text { Beta } \\
\end{array}$} & \multirow[t]{2}{*}{ t } & \multirow[t]{2}{*}{ Sig. } \\
\hline & & B & Std. Error & & & \\
\hline \multirow[t]{6}{*}{1} & (Constant) & .309 & .020 & & 15.734 & .000 \\
\hline & ROA & -.069 & .002 & -.461 & -31.580 & .000 \\
\hline & CR & -.002 & .003 & -.011 & -.611 & .544 \\
\hline & DER & .003 & .003 & .022 & .919 & .363 \\
\hline & DTA & -.005 & .006 & -.024 & .911 & .367 \\
\hline & & .824 & .009 & 1.213 & 92.072 & .000 \\
\hline
\end{tabular}

a. Dependent Variable: Dividend payout ratio (DPR)

\section{SIMPULAN}

Sebanyak 50 sampel diambil secara purposive sampling dari 137 perusahaan sektor industri yang terdaftar di Bursa Efek Indonesia untuk tahun 2011. Variabel bebas (independent variables) adalah return on assets (ROA), current ratio (CR), debt to equity ratio (DER), debt to total assets (DTA), dan net income aftar tax (NIAT) serta variabel terikat (dependent variable) adalah divident payout ratio (DPR) terdistribusi secara normal serta memenuhi syarat regresi. Variabel bebas (independent variables) yang diteliti dalam penelitian ini sebesar 99,5\% berpengaruh terhadap dividend payout ratio. Sedangkan sisanya, sebesar $0,05 \%$, dijelaskan oleh variabel bebas di luar penelitian ini. Hasil penelitian ini menjelaskan bahwa return on assets (ROA) dan net income after tax (NIAT) secara signifikan berpengaruh terhadap dividend payout ratio (DPR). Sedangkan current ratio (CR), debt to equity ratio (DER), debt to total assets (DTA) secara signifikan tidak berpengaruh terhadap divident payout ratio (DPR). Penelitian ini dapat dikembangkan peneliti lain dengan objek penelitian selain perusahaan sektor industri, seperti perusahaan jasa umum, perusahaan dagang dan distributor, perusahaan jasa khusus seperti perbankan, rumah sakit, asuransi, dan perhotelan. Para investor dalam melakukan investasi saham, khususnya pada kelompok perusahaan sektor industri memerhatikan besarnya nilai rasio keuangan seperti return on asset dan net income after tax. 


\section{DAFTAR PUSTAKA}

Brigham, E. F., \& Ehrhardt, M. C. (2008). Financial Management Theory and Practice (12 ${ }^{\text {th }}$ Edition). Ohio: Thompson South Western.

Brigham, E. F., \& Houston, J. F. (2009). Fundamental of Financial Management (12 ${ }^{\text {th }}$ Edition). Ohio: Thompson South Western.

Hanafi, M. M. (2004). Manajemen Keuangan. Yogyakarta: BPFE, UGM.

Handayani, \& Hadinugroho, B. (2009). Analisis pengaruh kepemilikan managerial, kebijakan hutang, ukuran perusahaan terhadap kebijakan dividen: studi kasus perusahaan manufaktur yang terdaftar di bursa efek Indonesia. Jurnal Fokus Managerial, 6(1), 64-71.

Ikatan Akuntan Indonesia. (2009). Standar Akuntansi Keuangan. Jakarta: Salemba Empat.

Manurung, I. A., \& Siregar, H. S. (2009). Pengaruh laba bersih dan arus kas operasi terhadap kebijakan dividen pada perusahaan manufaktur go publik. Jurnal Akuntansi, (3), 1-12. Universitas Sumatra Utara.

Maria, Destry, Eka, \& Priyantini. (2007). Diterminan Dividend Payout Perusahaan yang Listed di Bursa Efek Jakarta. The 1st PPM National Conference on Management Research: Manajemen di Era Globalisasi. Hal 1-11.

Marlina, L., \& Danica, C. (2009). Analisis pengaruh cash position, debt to equity ratio, dan return on assets terhadap dividend payout ratio. Jurnal Manajemen Bisnis, 2(1), 1-6.

Mumaiza, L., \& Nasution, F. N. (2009). Analisis hubungan antara laba akuntansi dan laba tunai dengan dividen kas pada perusahaan manufaktur yang terdaftar di bursa efek Indonesia. Jurnal Akuntansi, (24), 1-10. Universitas Sumatra Utara.

Prihantoro. (2003). Estimasi pengaruh dividend payout ratio pada perusahaan publik di Indonesia. Jurnal Ekonomi dan Bisnis, 8(1), 7-14.

Sartono, R. A. (2001). Manajemen Keuangan Teori dan Aplikasi (4th Edition). Yogyakarta: BPFE, UGM.

Stice, J. D., Stice, E. K., \& Skousen, K. F. (2007). Intermediate Accounting. Ohio: Thompson.

Sudarsi, S. (2002). Analisis faktor-faktor yang mempengaruhi divedend payout ratio pada industri perbankan yang listed di Bursa Efek Jakarta. Jurnal Bisnis dan Ekonomi, 9(1), 66-78.

Suharli, M. (2007). Pengaruh profitability dan investment opportunity set terhadap kebijakan dividen tunai dengan likuiditas sebagai variabel penguat: studi pada perusahaan yang terdaftar di Bursa Efek Jakarta. Jurnal Akuntansi dan Keuangan, 9(1), 9-17.

Sulastri \& Harmadi. (2009). Analisis pengaruh Return on Investment, Cash Ratio, Current Ratio, Debt to Total Assets, Earning Per Share, dan investment to Opportunity Set terhadap dividen kas: studi kasus perusahaan manufaktur yang terdaftar di Bursa Efek Jakarta periode 2004-2006. Jurnal Fokus Manajerial, 7(1), 37-53. 
Sunarto \& Kartika, A. (2003). Analisis faktor-faktor yang mempengaruhi dividen kas di Bursa Efek Jakarta. Jurnal Bisnis dan Ekonomi, 1-14.

Sutrisno. (2001). Analisis faktor-faktor yang mempengaruhi dividend payout ratio pada perusahaan publik di Indonesia. TEMA, 2(1), 1-12.

Wirjolukito, A., Yanto, H., \& Sandy. (2003). Faktor-faktor sebagai pertimbangan dalam keputusan pembagian dividen pada perusahaan go publik di Indonesia. Jurnal Ekonomi dan Bisnis, 3(2), $160-172$. 


\section{LAMPIRAN}

\begin{tabular}{|c|c|c|c|c|c|c|}
\hline Kode Persahaan & ROA & CR & DER & DTA & NIAT & DPR \\
\hline AALI & 0,368659 & 1,630039 & 0,283351 & 0,214941 & 6,295221 & 0,302300 \\
\hline AKRA & 0,054668 & 1,162894 & 1,565280 & 0,571774 & 5,281506 & 0,312500 \\
\hline ANTM & 0,426358 & 4,474107 & 0,373491 & 0,271901 & 6,710326 & 0,400700 \\
\hline AQUA & 0,073932 & 7,091572 & 0,744424 & 0,423516 & 4,818971 & 0,191800 \\
\hline ASGR & 0,115400 & 1,335758 & 0,988554 & 0,497122 & 4,857779 & 0,388500 \\
\hline ASII & 0,102634 & 0,912431 & 1,168720 & 0,496095 & 6,814199 & 0,383200 \\
\hline AUTO & 0,131695 & 2,555690 & 0,484093 & 0,316923 & 5,657923 & 0,400500 \\
\hline UNSP & 0,047919 & 3,172973 & 0,806771 & 0,446383 & 5,315078 & 0,196400 \\
\hline BUDI & 0,031082 & 1,491964 & 1,313158 & 0,553284 & 4,664426 & 1,480100 \\
\hline CLPI & 0,058228 & 1,637362 & 1,289198 & 0,563166 & 3,989361 & 0,352000 \\
\hline DLTA & 0,079903 & 4,172466 & 0,286946 & 0,222070 & 4,675146 & 0,669200 \\
\hline EPMT & 0,110603 & 1,910355 & 0,858170 & 0,461836 & 5,364832 & 0,234900 \\
\hline FAST & 0,152889 & 1,280134 & 0,668153 & 0,400535 & 5,010881 & 0,203100 \\
\hline FORU & 0,038237 & 1,715343 & 1,244952 & 0,553968 & 3,862251 & 0,204400 \\
\hline GDYR & 0,073144 & 1,352377 & 0,935274 & 0,483277 & 4,627356 & 3,029400 \\
\hline GGRM & 0,060328 & 2,250558 & 0,693313 & 0,409104 & 6,159442 & 0,358100 \\
\hline HMSP & 0,231116 & 1,779658 & 0,944298 & 0,485595 & 6,559190 & 0,123800 \\
\hline BRAM & 0,025178 & 4,976096 & 0,517169 & 0,297359 & 4,592721 & 0,593500 \\
\hline INTP & 0,098211 & 2,960177 & 0,443049 & 0,306365 & 5,992857 & 0,316300 \\
\hline INDF & 0,033202 & 0,920971 & 2,621033 & 0,632599 & 5,991384 & 0,399000 \\
\hline INDS & 0,016500 & 1,070526 & 6,610902 & 0,868436 & 3,995108 & 0,058900 \\
\hline IGAR & 0,046774 & 3,062112 & 0,527533 & 0,303581 & 4,188253 & 0,428700 \\
\hline KLBF & 0,137342 & 4,982591 & 0,331144 & 0,218274 & 5,848616 & 0,179600 \\
\hline LTLS & 0,033568 & 0,829356 & 2,464160 & 0,676481 & 4,855337 & 0,304800 \\
\hline LION & 0,117050 & 5,408134 & 0,272326 & 0,214038 & 4,403086 & 0,185600 \\
\hline LMSH & 0,094600 & 1,8548006 & 1,155451 & 0,536060 & 3,773933 & 0,624000 \\
\hline MTDL & 0,024504 & 1,280095 & 2,882282 & 0,704995 & 4,454540 & 0,068200 \\
\hline MLBI & 0,135703 & 0,591206 & 2,144556 & 0,681898 & 4,926265 & 1,421700 \\
\hline MICE & 0,120520 & 7,785637 & 0,155814 & 0,123251 & 4,477295 & 0,501200 \\
\hline MRAT & 0,035222 & 7,680225 & 0,119971 & 0,115273 & 4,046495 & 0,250000 \\
\hline PANR & 0,917590 & 1,052110 & 1,637698 & 0,579118 & 3,850891 & 0,099600 \\
\hline PJAA & 0,110299 & 2,646243 & 0,568452 & 0,362232 & 5,148809 & 0,451900 \\
\hline POOL & 0,057845 & 0,727430 & 1,722143 & 0,583240 & 4,087604 & 0,317100 \\
\hline PNSE & 0,102427 & 14,937758 & 0,065330 & 0,061304 & 4,146376 & 4,243700 \\
\hline RUIS & 0,087150 & 2,876795 & 1,290582 & 0,563416 & 4,555820 & 0,307300 \\
\hline RALS & 0,125726 & 2,290992 & 0,354481 & 0,261710 & 5,564440 & 0,509600 \\
\hline RIGS & 0,029718 & 2,912635 & 0,554487 & 0,356701 & 4,450926 & 0,528000 \\
\hline SMSM & 0,096771 & 1,709245 & 0,656479 & 0,381371 & 4,904851 & 1,573900 \\
\hline SMGR & 0,208498 & 3,643410 & 0,270947 & 0,210874 & 6,249298 & 0,505800 \\
\hline SMAR & 0,122650 & 1,720322 & 1,285317 & 0,562423 & 5,995172 & 0,494100 \\
\hline SOBI & 0,111792 & 0,834214 & 0,826362 & 0,432864 & 4,973982 & 0,316500 \\
\hline IKBI & 0,131451 & 3,090547 & 0,339219 & 0,253296 & 4,889117 & 0,391600 \\
\hline SCMA & 0,049761 & 2,049467 & 0,106109 & 0,514821 & 5,103807 & 0,409060 \\
\hline TLKM & 0,156681 & 0,772836 & 1,165086 & 0,475335 & 7,109140 & 0,563700 \\
\hline TSPC & 0,100377 & 4,081339 & 0,263924 & 0,201349 & 5,444604 & 1,052600 \\
\hline TGKA & 0,034989 & 1,351440 & 3,565479 & 0,777349 & 4,673859 & 0,331800 \\
\hline TBLA & 0,039569 & 1,811270 & 1,623833 & 0,617886 & 4,987787 & 1,143000 \\
\hline TURI & 0,056742 & 1,146937 & 2,906418 & 0,743950 & 5,278333 & 0,224000 \\
\hline UNVR & 0,368367 & 0,871747 & 0,980367 & 0,494860 & 6,293286 & 0,998400 \\
\hline UNTR & 0,114826 & 1,339363 & 1,258680 & 0,554998 & 6,174071 & 0,400100 \\
\hline
\end{tabular}

